\title{
Study on Plant Geometry, Cultivar and Fertilizer Doses on Growth and Yield of Parthenocarpic Cucumber under Protected Condition
}

\author{
Bhoopendra Singh*, Devi Singh and V.M. Prasad \\ Department of Horticulture, Sam Higginbottom University of Agriculture Technology and \\ Sciences, Prayagraj, Allahabad-211007, U.P, India \\ *Corresponding author
}

\section{Keywords}

Cucumber,

Parthenocarpic,

Growth, Yield,

Polyhouse, Cultivar,

Plant geometry,

Dose of fertilizers

Article Info

Accepted:

10 May 2019

Available Online:

10 June 2019

\section{A B S T R A C T}

The present investigation was conducted 2017-18 and 2018-19 carried out at Vegetable Research Farm SHUATS, Prayagraj, Allahabad U.P. with three replications. In this way the experiments were comprising of total twenty seven treatment combinations of three cultivars namely, Pant Parthenocarpic Cucumber $-2\left(\mathrm{~V}_{1}\right)^{\prime}$ Pant Parthenocarpic Cucumber $-3\left(\mathrm{~V}_{2}\right)$ and Hilton $\left(\mathrm{V}_{3}\right)$; three plant geometry i.e. $60 \times 30 \mathrm{~cm}\left(\mathrm{P}_{1}\right), 60 \times 40 \mathrm{~cm}\left(\mathrm{P}_{2}\right)$ and $60 \times 50 \mathrm{~cm}\left(\mathrm{P}_{3}\right)$ and three NPK, fertilizers doses like, 20:10:22 Kg/1000m ${ }^{2}\left(D_{1}\right), 25: 15: 27 \mathrm{Kg} / 1000 \mathrm{~m}^{2}\left(\mathrm{D}_{2}\right)$ and 30:20:32 Kg/1000 $\mathrm{m}^{2}\left(\mathrm{D}_{3}\right)$. The fertilizers dose applies at twice a week. Similar treatments were applied during both the year. The results revealed that all the treatments and their combinations had significantly influenced the growth, and yield of fruits during both the year of experimentation. Among the different cultivars used in the study, Pant Parthenocarpic Cucumber $-3\left(\mathrm{~V}_{2}\right)$ were found statistically superior to enhance vine length $(2.73 \mathrm{~m})$, stem girth $(0.80 \mathrm{~cm})$ leaf area $\left(412.34 \mathrm{~cm}^{2}\right)$, Internodal distance $(8.38 \mathrm{~cm})$ minimum days required to first flower bud initiation (42.14 DAS), minimum days required to first fruit harvest (55.42 DAS), which ultimately gave maximum yield per vine $(2.82 \mathrm{~kg}$ per plant $)$ during pooled data respectively. Further, among the various spacing treatments, spacing $\left(\mathrm{P}_{3}\right)$ i.e. $60 \times 50 \mathrm{~cm}$ was found to be significantly superior with respect to vegetative growth and yield per plant of fruits except yield per sq. meter in both the year Significantly higher yield per sq. meter was recorded in spacing $\mathrm{P}_{1}(60 \times 30 \mathrm{~cm})$ and least in $\mathrm{P}_{3}(60 \times 50 \mathrm{~cm})$ during both the year. In case of dose fertilizer application, the application of fertilizers through manually apply the root zone of plant was found superior to maximum fertilizers apply compared to minimum fertilizers apply during both the year Maximum number of fruits per vine, average fruit weight $(\mathrm{g})$, yield per vine $(\mathrm{kg})$ and yield per sq. meter $(\mathrm{kg})$ were recorded in both the year maximum fertilizers apply in $\mathrm{D}_{3}$. Therefore, it is recommended that cucumber should be grown at a spacing of $60 \times 50 \mathrm{~cm}$ along with $\mathrm{D}_{3}$ NPK dose using cultivars (Pant Parthenocarpic Cucumber -3) during the both the year for sustaining higher fruit yield cucumber under polyhouse condition. Whereas, on the basis of benefit cost ratio, it could be recommended that cucumber cultivar 'Pant Parthenocarpic Cucumber -3' should be grown at a spacing of $60 \times 50 \mathrm{~cm}$ along with the maximum NPK dose of fertilizers apply during both the year for attaining the maximum production of cucumber polyhouse condition. 


\section{Introduction}

Cucumber (Cucumis sativus L.) is one of the most important vegetable crops of the cucurbitaceace family and having a chromosome number, $2 \mathrm{n}=14$. As a vegetable crop parthenocarpic cucumber has great economic importance. The immature fruit of cucumber are use as salad and for making pickles, pahari rayata and brined on commercial scale (Bairagi et al., 2013). The global production of cucumber is 71.36 million tons (FAOSTAT 2014) and commercially cultivated in countries like China, India, Turkey, Iran, Japan, Europe and United States. In the world more than 55 countries adopted protected cultivation technology; China has the largest area of 2.7 mha under protected cultivation Kacira (2011). The total area of protected cultivation in India is approx 30,000 ha. Contributes $0.23 \%$ of the total area under the horticulture crop cultivation in India at and of $11^{\text {th }}$ five year plan (Shweta et al., 2014). The total area of cucumber growing In India 78,000 hectares with an annual production of 11.42 lakh MT (National Horticulture Board 2016-17). The main areas of cucumber cultivation are river beds of Yamuna, Ganges and Narmada in North and Kaveri, Krishna and Godavari in South (Singh 1998).

\section{Materials and Methods}

The present investigation was conducted during 2017-2019 at the Vegetable Research Farm, Department of Horticulture, Sam Higginbottom University of Agriculture, Technology \& Science, Prayagraj, Allahabad (U.P.) during the year 2017-18 and 20182019. The experimental situated in the river basin of the Ganga and Yamuna. It is situated at $28^{0} .87^{\prime} \mathrm{N}$ latitude $81^{\circ} .15^{\prime} \mathrm{E}$ longitude with an altitude of $98 \mathrm{~m}$ above the mean sea level. Average annual rainfall is $1013.4 \mathrm{~mm}$ The polyhouse was covered with ultra violet stabilized low density polyethylene sheet having 200 micron thickness. The experiment was comprising of total twenty seven treatment combinations of three level of spacing viz. $60 \times 30 \mathrm{~cm}(\mathrm{P} 1), 60 \times 40 \mathrm{~cm}(\mathrm{P} 2)$ and $60 \times 50 \mathrm{~cm}(\mathrm{P} 3)$, three cultivar viz. Pant Parthenocarpic Cucumber -2 (V1), Pant Parthenocarpic Cucumber -3 (V2)and Hilton (V3) with three dose of fertilizers level viz. D1 20:10:22 kg/1000 sq.m, D2 25:15:27 kg /1000 sq.m and D3 30:20:32 kg/1000 sq.m. The experiment was laid out following factorial randomized block design (Factorial RBD) with three replications. Observations were recorded for ten different characteristics related to vegetative growth and yield attributing traits. The economics of different treatments were determined on the basis of prevailing market price of inputs and produce. The data recorded for various characters were subjected to statistical analysis using analysis of variance (ANOVA) under factorial RBD.

\section{Results and Discussion}

The result, it has been revealed that the effect of cultivars a significant influence on plant height, stem girth, leaf area and Internodal distance of cucumber under polyhouse condition. Maximum plant height $(2.73 \mathrm{~m})$, stem girth $(0.80 \mathrm{~cm})$, leaf area $\left(412.34 \mathrm{~cm}^{2}\right)$, and Internodal distance $(41.14 \mathrm{~cm})$ was measured in Pant Parthenocarpic Cucumber 3. However, polyhouse environment favourable condition the growth of the lines by modifying the natural environment and micro climatic conditions surrounding the plants Plant geometry significantly affected the plant height, stem girth, leaf area and Internodal distance of cucumber. Plants at wider spacing $(60 \times 50 \mathrm{~cm})$ gave maximum plant height $(2.74 \mathrm{~m})$, stem girth $(0.79 \mathrm{~cm})$, leaf area $\left(411.56 \mathrm{~cm}^{2}\right)$, and Internodal distance $(8.33 \mathrm{~cm})$ than closer spacing (60 $\mathrm{x} 30 \mathrm{~cm})$. This may be due to the availability of more space for the plants. Significant linear 
increase of main vine length, stem girth, leaf area and Internodal distance was reported with increased spacing. The results obtained on effect of dose of fertilizer application on plant height, stem girth, leaf area and Internodal distance of cucumber indicated that all the characters were significantly.

A perusal of data presented in clearly indicated that the cultivar PPC-3 $\left(\mathrm{V}_{2}\right)$ exhibited significantly higher plant height, stem girth, leaf area, Internodal distance (3.04 $\mathrm{m}, \quad 0.85 \mathrm{~cm}, 422.60 \mathrm{~cm}^{2}$ and $\left.8.11 \mathrm{~cm}\right)$, respectively in spacing $S_{3}(60 \times 50 \mathrm{~cm})$ as compared to $S_{1}(60 \times 30 \mathrm{~cm})$ along with the $D_{3}$ maximum dose of fertilizers application. This difference in varietal performance of cucumber during winter season may be due to varietal characteristics. The data presented clearly showed that effect of cultivars, spacing and dose of fertilizer along with their interaction effects had significantly influenced the minimum days to first flower bud initiation (42.13 DAS) was reported in cultivar $\mathrm{V}_{2}$ (Pant parthenocarpic cucumber 2), spacing $\mathrm{P}_{3}$ (41.06 DAS) which was found at par with spacing $\mathrm{P}_{2}$ and $\mathrm{P}_{1}$ (42.04 and 44.31 DAS respectively) and with Fertigation minimum days required to first flower bud initiation $\mathrm{D}_{3}$, (42.11 DAS). Minimum number of days required to first fruit harvest $(55.42$ DAS) was observed in cultivar Pant Parthenocarpic Cucumber -3 , in spacing $\mathrm{P}_{3}$ $(60 \times 50 \mathrm{~cm})$ with 56.07 days and 55.71 days through maximum dose of fertilizers, $D_{3}$ 30:20:32 Kg (Table 4.11). However, the interaction effects of cultivars, plant geometry and dose of fertilizer application, among different cultivars, maximum number of fruits per plant (21.89), minimum number of unmarketable fruits per plants (1.46) and highest fruit weight (116.41 g) was obtained in cultivar Pant Parthenocarpic Cucumber -3.

Table.1 Study of cultivars, spacing and dose of fertilizer application of parthenocarpic cucumber under polyhouse condition during winter season 2017-19 pooled

\begin{tabular}{|c|c|c|c|c|c|c|c|c|c|c|}
\hline Treatment & $\begin{array}{l}\text { Plant } \\
\text { height } \\
\text { (m) }\end{array}$ & $\begin{array}{l}\text { Stem } \\
\text { girth } \\
(\mathrm{cm})\end{array}$ & $\begin{array}{l}\text { Leaf } \\
\text { area } \\
\left(\mathrm{cm}^{2}\right)\end{array}$ & $\begin{array}{l}\text { Internodal } \\
\text { distance } \\
(\mathrm{cm})\end{array}$ & $\begin{array}{l}\text { Days to } \\
\text { first } \\
\text { flower } \\
\text { bud } \\
\text { initiate } \\
\text { (DAS) }\end{array}$ & $\begin{array}{l}\text { Days } \\
\text { of first } \\
\text { fruits } \\
\text { picking } \\
\text { (DAS) }\end{array}$ & $\begin{array}{l}\text { Number } \\
\text { of fruit } \\
\text { per } \\
\text { plant }\end{array}$ & $\begin{array}{l}\text { Fruit } \\
\text { weight } \\
\text { (g) }\end{array}$ & $\begin{array}{l}\text { Fruits } \\
\text { yield } \\
\text { per } \\
\text { plants } \\
\text { (Kg) }\end{array}$ & $\begin{array}{l}\text { Yield } \\
\text { per } \\
\text { square } \\
\text { meter } \\
\text { (Kg) }\end{array}$ \\
\hline \multicolumn{11}{|l|}{ Cultivar } \\
\hline $\mathrm{V}_{1}, \mathrm{PPC}-2$ & 2.69 & 0.77 & 406.14 & 8.47 & 42.32 & 57.35 & 19.78 & 116.11 & 2.58 & 12.86 \\
\hline $\mathrm{V}_{2}, \mathrm{PPC}-3$ & 2.73 & 0.80 & 412.34 & 8.38 & 42.14 & 55.42 & 21.89 & 116.41 & 2.82 & 13.46 \\
\hline $\mathbf{V}_{3}$, Hilton & 2.73 & 0.78 & 408.02 & 8.34 & 42.95 & 57.13 & 20.43 & 116.27 & 2.73 & 12.93 \\
\hline \multicolumn{11}{|c|}{ Dose of Fertilizers kg/1000 sq.m } \\
\hline$D_{1}, 20: 10: 22$ & 2.68 & 0.76 & 406.55 & 8.51 & 42.63 & 57.22 & 19.91 & 114.39 & 2.56 & 12.89 \\
\hline$D_{2}, 25: 15: 27$ & 2.70 & 0.78 & 407.68 & 8.41 & 42.67 & 56.97 & 20.62 & 116.44 & 2.73 & 13.03 \\
\hline D3, 30:20:32 & 2.78 & 0.81 & 412.27 & 8.27 & 42.11 & 55.71 & 21.58 & 117.96 & 2.85 & 13.33 \\
\hline \multicolumn{11}{|c|}{ Plant geometry in $\mathrm{cm}$. } \\
\hline$P_{1}, 60 \times 30$ & 2.68 & 0.78 & 406.18 & 8.48 & 44.31 & 57.27 & 20.18 & 113.42 & 2.61 & 14.57 \\
\hline$P_{2}, 60 \times 40$ & 2.74 & 0.78 & 408.76 & 8.39 & 42.04 & 56.56 & 20.69 & 116.92 & 2.71 & 13.77 \\
\hline$P_{3}, 60 \times 50$ & 2.73 & 0.79 & 411.56 & 8.33 & 41.06 & 56.07 & 21.24 & 118.45 & 2.81 & 10.91 \\
\hline F - test & $\mathbf{S}$ & $\mathbf{S}$ & $\mathbf{S}$ & $\mathbf{S}$ & $\mathbf{S}$ & $\mathbf{S}$ & $\mathbf{S}$ & $\mathbf{S}$ & $\mathbf{S}$ & $\mathbf{S}$ \\
\hline S. Ed. ( \pm$)$ & 0.002 & 0.002 & 0.04 & 0.020 & 0.103 & 0.071 & 0.058 & 0.021 & 0.014 & 0.034 \\
\hline CD at $5 \%$ & 0.003 & 0.004 & 0.09 & 0.041 & 0.209 & 0.144 & 0.118 & 0.042 & 0.028 & 0.068 \\
\hline
\end{tabular}


This might be due to more fruit set, more photosynthesis as it produced more vine length and leaf area during the processes. Number of fruits per vine and average fruit weight were significantly influenced by plant geometry (Table 4.13 to 4.22). Maximum number of fruits per vine (21.24), and highest average fruit weight (118.45 g) was reported in $60 \times 50 \mathrm{~cm}$ spacing $\left(\mathrm{P}_{3}\right)$ as compared to lowest in $\mathrm{P}_{1}(60 \times 30 \mathrm{~cm})$. The pooled analysis recorded $\mathrm{P}_{3}$ as having significantly higher number of fruits per plant and average fruit weight this may be due to the availability of more space for the plants growth. The results obtained in present investigation revealed that the dose of fertilizer application had a significant influence on number of fruits per vine, and average weight of fruit (Table-1). Higher number of fruits per plant (21.58), and maximum average fruit weight $(117.96 \mathrm{~g})$ was obtained in $\mathrm{D}_{3}$ maximum dose of fertilizers (30:20:32 Kg) as compared to that in $D_{1}$ minimum dose of fertilizers application. Interaction effect of cultivars, spacing and dose of fertilizer application on number of fruits per vine, and maximum average fruit weight were found to have a significant effect (Table 1). Maximum yield per plant $(2.82 \mathrm{~kg})$ was noticed in cultivar $\left(\mathrm{V}_{2}\right)$ Pant Parthenocarpic Cucumber -3 , followed by (2.73 $\mathrm{kg}$ per plant) in Hilton which was found significantly at par with $(2.58 \mathrm{~kg}$ per plant) cultivar Pant Parthenocarpic Cucumber -2 . All the three cultivars had significant effect on yield per plant of parthenocarpic cucumber. Maximum yield per plant $(2.81 \mathrm{~kg})$ was observed in spacing $\mathrm{P}_{3}(60 \times 50 \mathrm{~cm})$ as compared to $2.61 \mathrm{~kg}$ per plant in $\mathrm{P}_{1}(60 \times 30$ $\mathrm{cm})$. It is concluded that total yield significantly increased as the spacing between plants within rows was increased. Dose of fertilizer application was found to have a significant effect on yield per plant of cucumber. Higher yield (2.85 kg per plant). recorded maximum yield per plant $(\mathrm{kg})$ and yield per ha (t) in cucumber hybrid when
150:90:90 kg NPK per hectare was applied through fertigation. Interaction of cultivars, spacing and dose of fertilizer had significant influence on yield per vine of cucumber (Table-1). Maximum yield per vine $(3.20 \mathrm{~kg}$ per vine).

\section{References}

AVRDC, (1999). Vegetable production. AVRDC, shanhua, tianan, Taiwan, pp. 182

Bairagi, S.K, Singh, D.K, and Ram, H.H. (2013). Analysis of combining ability in cucumber (Cucumis sativus L.) through half dialled mating system. Annals of Horticulture, 6 (2): 308-314

FAOSTAT (2014). "Major crops - by countries/regions, rankings; choose cucumber and gherkins, world". Food and Agricultural Organization.

Lal, M., Kanwar, H.S. and Kanwar, R. (2014). Impact of spacing and training on seed yield of capsicum, Capsicum annum L. under protected condition. International Journal of Farm Science. 4(3): 42-48.

NHB Data Base. 2014. National Horticulture Board Department of Agriculture and Co-operation, Government of India.

Sharma, M.K. (2009). Effect of different growing media and fertigation levels on production of cucumber (Cucumis sativus) under protected conditions in the hills. Indian J. Agril. Sci., 79(11): 853-856.

Shweta, S., Bhatia, K. and Malik, M. (2014). Protected Farming, Popular Kheti Volume -2, Issue-1 (January-March)

Singh, B. 2005. Protected Cultivation of Vegetable Crops. Kalyani Publishers, Ludhiana: 74-84.

Singh, B., Kumar, M. 2006. Technoeconomic feasibility of Israeli and indigenously designed naturally ventilated greenhouses for year-round 
cucumber cultivation. ActaHorticulturae. 710: 535-538.

Singh, D.N. and Chhonkar, V.S. (1986), Effect of nitrogen, phosphorus, potassium and spacings on growth and yield of muskmelon (Cucumis melo L.). Indian J. Hort., 43(3-4): 265- 269.

Vikram Kumar Kapuriya, K.D. Ameta, Suresh Kumar Teli, Akshay Chittora, Suman Gathala and Satveer Yadav, 2017. Effect of spacing and training on growth and yield of polyhouse grown cucumber (Cucumis sativus L.). Int. J. Curr. Microbiol. App. Sci., 6(8): 299304.

Yadav A R et al., (2013). Effect of dates of planting and spacing on growth and yield characteristics of ginger (Zingiber officinale Ros.) var. IISR Mahima. Journal of Spices and Aromatic CropsVol. 22 (2): 209-214.

\section{How to cite this article:}

Bhoopendra Singh, Devi Singh and Prasad, V.M. 2019. Study on Plant Geometry, Cultivar and Fertilizer Doses on Growth and Yield of Parthenocarpic Cucumber under Protected Condition. Int.J.Curr.Microbiol.App.Sci. 8(06): 1061-1065. doi: https://doi.org/10.20546/ijcmas.2019.806.130 